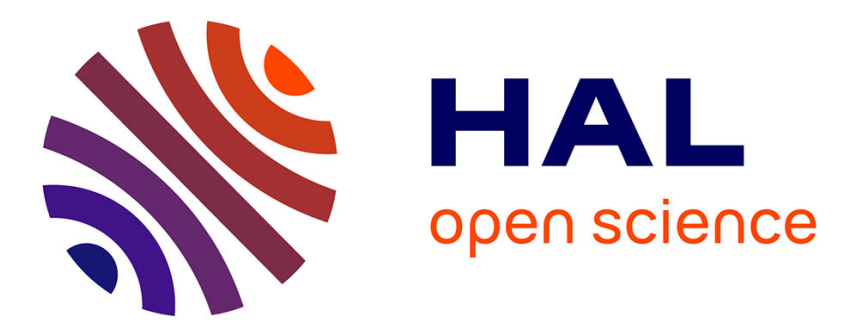

\title{
HIGH SPIN ISOMERIC STATES IN 197Pb
}

\author{
H. Richel, G. Albouy, G. Auger, J. Lagrange, M. Pautrat, C. Roulet, H. \\ Sergolle, J. Vanhorenbeeck
}

\section{To cite this version:}

H. Richel, G. Albouy, G. Auger, J. Lagrange, M. Pautrat, et al.. HIGH SPIN ISOMERIC STATES IN 197Pb. Congress of the French Physical Society, 1977, Poitiers, France. pp.C3-168-C3-168, 10.1051/jphyscol:1978327 . jpa-00217431

\section{HAL Id: jpa-00217431 https://hal.science/jpa-00217431}

Submitted on 1 Jan 1978

HAL is a multi-disciplinary open access archive for the deposit and dissemination of scientific research documents, whether they are published or not. The documents may come from teaching and research institutions in France or abroad, or from public or private research centers.
L'archive ouverte pluridisciplinaire HAL, est destinée au dépôt et à la diffusion de documents scientifiques de niveau recherche, publiés ou non, émanant des établissements d'enseignement et de recherche français ou étrangers, des laboratoires publics ou privés. 


\title{
HIGH SPIN ISOMERIC STATES IN ${ }^{197} \mathrm{~Pb}$
}

\author{
H. RICHEL (*), G. ALBOUY, G. AUGER, J. M. LAGRANGE, M. PAUTRAT, \\ C. ROULET, H. SERGOLLE and J. VANHORENBEECK (*)
}

Institut de Physique Nucléaire, B.P. 1, 91406 Orsay, France

High spin isomeric states in ${ }^{197} \mathrm{~Pb}$ have been investigated by in-beam gamma ray technics. These states are produced in (heavy ion, $x \mathbf{n}$ ) reactions. The various experiments performed are summarized in table I.

The proposed level scheme is presented in figure. 1 . As can be seen on the figure, the ${ }^{197} \mathrm{~Pb}$ level scheme looks like those of ${ }^{198} \mathrm{~Pb}$ and ${ }^{196} \mathrm{~Pb}$ if the $13 / 2^{+}$ isomeric state is related to the $0^{+}$ground state in even lead isotopes. The $55 \mathrm{~ns}$ half life is due to a small unobserved E2 transition between the $33 / 2^{+}$ and $29 / 2^{+}$states. Low-energy E1 transitions $\left(21 / 2^{-} \rightarrow 21 / 2^{+} ; \quad 32 \mathrm{keV}\right.$ and $21 / 2^{-} \rightarrow 19 / 2^{+}$; $57 \mathrm{keV}$ ) account for the $700 \mathrm{~ns}$ half-life.

The higher spin states are well reproduced by a quasi-particule calculation (T.D.3 approximation with an S.D.I. interaction; $G_{\text {SDI }}=0.165 \mathrm{MeV}$ ) what favours a pure configuration interpretation, as was observed for the $12^{+}$and $10^{+}$levels in the even isotopes. The same agreement is not obtained for the lower lying levels, especially $17 / 2^{+}$and $15 / 2^{+}$; the position of these states, compared to that of the $2^{+}$ level suggests that they are members of the multiplet resulting from the weak coupling of a $2^{+}$core excitation with an i13/2 quasi-particle.
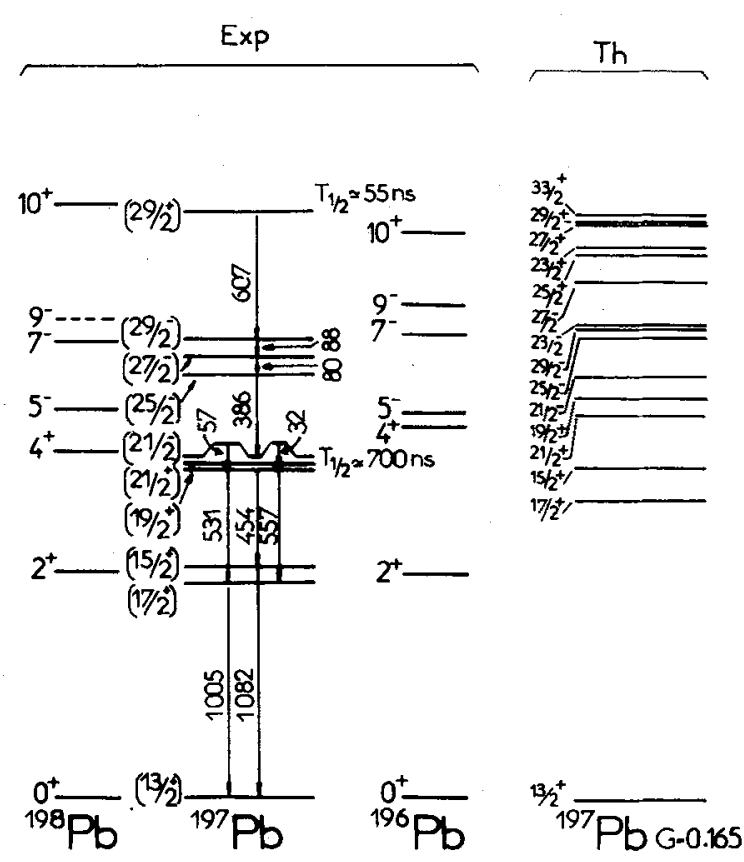

TABLE I

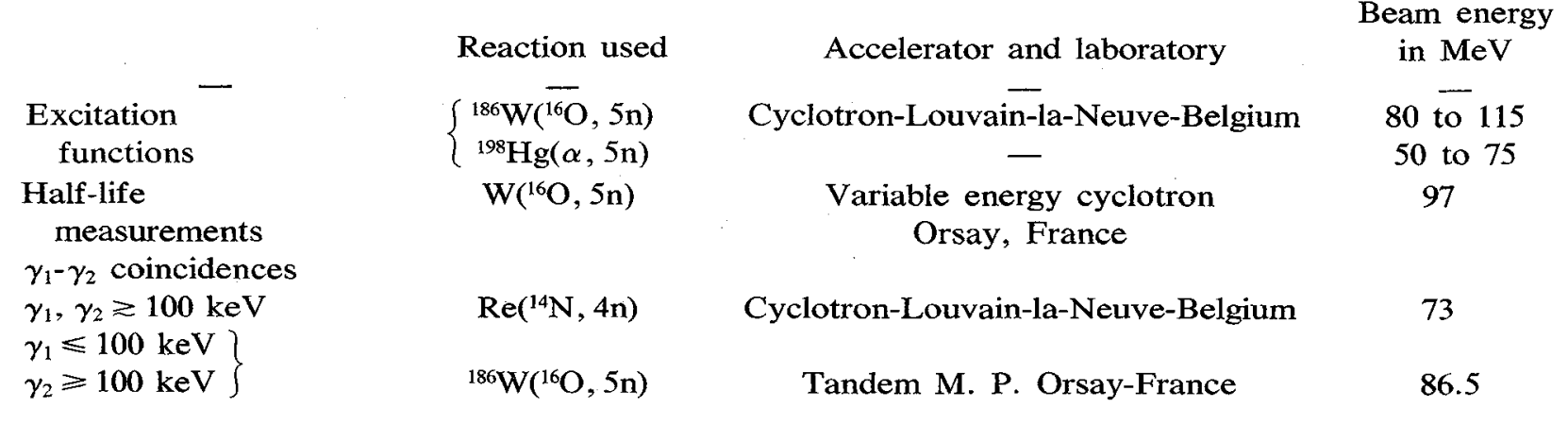

(*) I.I.S.N. Bruxelles, Belgique. 